\title{
Economic Impact of Practicing IPM Technology on Bitter Gourd (Momordica charantia L.) Production in Comilla District of Bangladesh
}

\author{
S. Islam ${ }^{1}$, D. M. S. Islam ${ }^{2}$ and R. Khanum ${ }^{2}$ \\ ${ }^{I}$ Department of Agricultural Economics, Bangabandhu Sheikh Mujibur Rahman Agricultural \\ University, Gazipur-1706, Bangladesh; ${ }^{2}$ Department of Agricultural Economics, Bangladesh \\ Agricultural University, Mymensingh-2202, Bangladesh \\ *Corresponding author and Email: shamima0613@gmail.com
}

Received: 21 July 2017

Accepted: 22 December 2017

\begin{abstract}
The present study was conducted to assess the economic impact of practicing Integrated Pest Management technology on bitter gourd production in Chandina upazila under Comilla district of Bangladesh. Sample survey was carried out over 70 bitter gourd producing farms. Out of 70 farmers, 35 for IPM and 35 for Non-IPM farmers were selected. The study revealed that majority of the farmers had moderately favorable attitude towards IPM technology for producing bitter gourd as shown by farmers' attitude index. IPM farmers earned more profit than Non-IPM farmers on bitter gourd production. The average total cost of bitter gourd production per hectare was estimated at about $\mathrm{Tk}$ 3,68,335 and 4,44,508 for IPM and Non-IPM farmers, respectively. The average gross returns per hectare were found at about Tk 8,60,016; 8,55,642; and 8,15,947 for marginal, small and medium IPM farmers, respectively. The same were Tk 8,22,654; 7,53,373 and 7,48,255 for marginal, small, and medium Non-IPM farmers, respectively. The estimated BCR was higher for IPM farmers (2.29) than Non-IPM farmers (1.69). Partial budget analysis showed that IPM technology was more profitable and net benefit was Tk 1,61,557. Although bitter gourd production was profitable, farmers faced several problems such as lack of training and technical knowledge, inadequate extension services, lack of marketing facilities etc. in using IPM technology.
\end{abstract}

Keywords: Integrated Pest Management (IPM), bitter gourd, variable cost, gross margin, profitability, partial budget.

\section{Introduction}

Bangladesh has made significant progress in vegetable production as well as export. Vegetables are cultivated in 9,31,000 acres of land and annual production of vegetables is 2,93,1000 metric tons (MT) (BBS, 2013). Bitter gourd (Momordica charantia L.) is one of the most popular cucurbitaceous vegetable in Bangladesh for its nutritive and medicinal value (Islam et al., 2013). It is grown extensively throughout the country during Kharif season which was cultivated in 23,890 acres and total production of 52,020 metric tons (BBS, 2013) per annum. Previously it was considered as homestead vegetable but now it is grown as field crop. The cucurbit fruit fly is a highly damaging pest of almost all the cucurbit vegetables (Nasiruddin et al., 2015). IPM approach for the cucurbits has been found as the most promising. In the study area though the majority of the growers are using conventional chemical control measures but the progressing and motivated 
growers and the members of the Integrated Crop Management (ICM) club are gradually adopting IPM methods for pest control, especially for fruit fly.

Bitter gourd producing farmers often fail to obtain the expected yield due to heavy damage caused by various insect, pests and diseases. As such farmers sprayed pesticides quite frequently due to pest alone annual yield loss was 25 percent for vegetables crops in every year (FAO, 2001). For increasing productivity, farmers are intensively using the improved food production technology and pesticides. Both over use and misuse of pesticides may lead to loss of effectiveness of pesticides due to the development of resistance and could cause human health hazards and environmental pollution. To overcome increasing problems associated with the strategy of exclusive and indiscriminate use of pesticides, the concept of integrated control was first articulated by entomologists (Stern et al., 1959) as an approach that applied ecological principles in utilizing biological and chemical control methods against insect pests. To reduce the use of pesticides on vegetables, Integrated Pest Management (IPM) practices have been introduced in Bangladesh. IPM means to control pests on the basis of sound biological knowledge and principles so that the vegetables can be produced successfully without affecting the yield.

Presently a large number of farmers in different regions of Bangladesh are producing huge amount of vegetables by using eco-friendly pheromone trap instead of harmful pesticides and are being financially benefited by using the trap at lesser cost compared to that of using pesticides (Anonymous, 2015). Although pesticides may provide temporary relief, it is now widely accepted that indiscriminate and excessive use of pesticides and the long-term dependency on them threaten the sustainability of agricultural production. Indiscriminate use of pesticides by farmers to control the pest has endangered the safety of the environment and increased the chances of accumulation of poisonous residues in the produce (Nasiruddin et al., 2015). IPM has a broad approach to vegetable production based on a sound ecological understanding. It also helps to grow healthy vegetables and to increase farm production and income on a sustainable basis while improving the environment and community health at the same time.

However, very few economic studies (Islam, 2014; Islam et al., 2013; Chowdhury, 2011; and Suraia, 2008) were conducted on IPM technology on bitter gourd production. Some studies (Rashid, 2001 and Hoque, 2001) addressed the attitudes, problems etc. in producing bitter gourd. The present study was designed to compare the profitability of bitter gourd production between IPM and Non-IPM farmers in the study areas. This study also provides valuable information for formulating appropriate policy for both IPM and Non-IPM farmers in practicing IPM technology. This study will be able to give latest information about practicing IPM technology on bitter gourd production especially in the study areas. Therefore, much work is required to enhance the empirical knowledge about IPM technology in the study areas. The present study makes an attempt to analyse economic impact of practicing IPM technology on bitter gourd production in Comilla District of Bangladesh. The specific objectives of the study were as follows: i) to determine farmers' attitude towards IPM technology adaptation; ii) to compare the profitability of bitter gourd production between IPM and Non-IPM farmers and iii) to suggest policy options in overcoming the perceived problems and exploring possible opportunities.

\section{Materials and Analytical Techniques Used}

A multistage sample technique was used in the study. On the basis of the specific objectives of the study, two villages namely Atbarpur and Chaykot under Chandina upazila of Comilla district was selected purposively because of higher bitter gourd production under supervision of the Department of Agricultural Extension (DAE) during summer season. From each 
village, about 35 farmers were selected. A total of 70 farmers were interviewed in which 21 IPM farmers and 14 Non-IPM farmers from Atbarpur and 21 Non-IPM and 14 IPM farmers from Chaykot village were selected randomly based on data availability. Out of 70 farmers, 35 for IPM adopted farmers and 35 for Non-IPM farmers were selected using purposive sampling technique. Primary data were collected during field visit for the period of July-August, 2015 through direct interview with structured interview guide. Due to unavailability of bitter gourd produced large farmers in the study areas, information was collected from three categorized farmers as marginal (having land up to 0.40 hectare), small (having land 0.40- 1.01 hectare) and medium farmer (having land 1.01-3.03 hectare) of IPM and Non-IPM farmers (BBS, 2013).

In order to achieve the objectives of the study, the following analytical techniques were used. Descriptive statistics such as sum, average, ratio, percentages etc. were derived and calculated by using Microsoft Excel. Independent sample t-test was also used to determine the differences between two groups of IPM and Non-IPM farmers for equal variances. The final results of the analysis were summarized and presented in tabular forms with their interpretations.

\subsection{Farmers' attitude towards IPM technology}

Farmers attitude towards IPM technology was the focus variable of the study. For measuring attitude of the respondents, a 5-point Likert Scale was used. There were 20 statements including both favor and disfavor against the 5-point scale. All the statements were arranged randomly to help avoiding subjects' bias in expressing their opinion. Each respondent was asked to indicate his/her attitude against each statement along a 5point scale, i.e., 'strongly agree', 'agree', 'no opinion', 'disagree' and 'strongly disagree'. Weights assigned to these responses were 4, 3, 2, 1 and 0 in favor and $0,1,2,3$ and 4 in disfavor (Ahmed, 2010). The total score of a respondent was determined by summing up the weights for responses against all the 20 statements. Attitude score of a respondent could, thus, range from 0 to 80 . In this case, 0 indicated no favorable attitude and 80 indicated highly favorable attitude. On the other hand, attitude score for each statement was calculated by using Attitude Index (AI) and it was calculated by using the following formula:

Attitude Index $(\mathrm{AI})=4 \times \mathrm{SA}+3 \times \mathrm{A}+2 \times \mathrm{NO}+$ $1 \times \mathrm{DA}+0 \times \mathrm{SDA}$ (in favor) ...............(1)

Or,

Attitude Index $(\mathrm{AI})=0 \times \mathrm{SA}+1 \times \mathrm{A}+2 \times \mathrm{NO}+$ $3 \times \mathrm{DA}+4 \times \mathrm{SDA}$ (in disfavor)

Where,

$\mathrm{SA}=$ Total number of respondents expressing their attitude 'strongly agree' for the statement;

$\mathrm{A}=$ Total number of respondents expressing their attitude 'agree' for the statement;

$\mathrm{NO}=$ Total number of respondents expressing their attitude 'no opinion' for the statement;

$\mathrm{DA}=$ Total number of respondents expressing their attitude 'disagree' for the statement; and

$\mathrm{SDA}=$ Total number of respondents expressing their attitude 'strongly disagree' for the statement.

\subsection{Profitability of bitter gourd production}

Per hectare profitability of bitter production was measured in terms of gross return, gross margin, net return and benefit cost ratio (undiscounted). The following formula was used to calculate the different parameters and the cost of production of bitter gourd:

\subsubsection{Gross return}

Gross return was calculated by multiplying the total volume of output of an enterprise by the average price in the harvesting period (Dillon and Hardaker, 1993). The following equation was used to estimate GR:

Gross return, GR $=\sum \mathrm{QP}$

Where,

GR = Gross return of bitter gourd production (Tk/ha);

$\mathrm{Q}=$ Quantity of bitter gourd production $(\mathrm{kg} / \mathrm{ha})$; and

$\mathrm{P}=$ Average price of bitter gourd $(\mathrm{Tk} / \mathrm{kg})$ 


\subsubsection{Gross margin}

Gross margin (GM) of farming enterprise is its output less the variable costs attributed to it (Barnard and Nix, 1999). Gross margin is the difference between revenue and cost before accounting for certain other costs. Generally, gross margin is calculated by the difference between gross return and variable costs.

That is,

Gross margin, $\mathrm{GM}=\mathrm{GR}-\mathrm{VC}$.

Where,

$\mathrm{GM}=$ Gross margin;

$\mathrm{GR}=$ Gross return; and

$\mathrm{VC}=$ Variable cost.

\subsubsection{Net return}

Net return was calculated by deducting total costs from the gross return. To determine the net return of bitter gourd production, the following equation was used:

Net return, NR $=$ GR - TC

Where,

GR $=$ Gross return; and

$\mathrm{TC}=$ Total cost.

This function determines the net return by subtracting the total cost of producing a particular commodity from its total return.

\subsubsection{Benefit Cost Ratio}

Benefit cost ratio (BCR) takes into account the amount of monetary gain realized by performing a research versus the amount it costs to execute that research. General rule of thumb is that if the benefit is higher than the cost $(\mathrm{BCR}>1)$ the project is a good investment. Considered as a relative measure which is used to compare benefit per unit of cost, BCR was estimated as ratio of gross returns and gross costs. The formula of calculating BCR (undiscounted) is shown as below:

Benefit cost ratio, $(\mathrm{BCR})=$ Gross return $/$ Total

cost...........................(6)

\subsection{Partial budget analysis}

Partial budget analysis is the tabulation of expected gains and losses due to a relative change (marginal) in farming method or technology. In the present study, partial budget framework was used to analyse the effect of using IPM technology for producing bitter gourd. Table 1 shows the partial budget format that facilitates analysis and comparison of alternatives.

\subsection{Identifying problems and possible opportunities in the study areas through problem confrontation index}

There were various problems faced by the farmers in adopting and practicing IPM technology in the study areas. The researcher identified the major problems confronted by the farmers. The farmers were asked to give their opinion on 8 selected problems which were identified during data collection. A four point rating scale was used for computing the problem score of a respondent. Each farmer was asked to indicate the extent of difficulty by each of the problem by checking any of the four responses such as 'high', 'medium', 'low' and 'not at all' and weights were assigned to these responses as $3,2,1$ and 0 respectively.

Table 1: Partial budget format

\begin{tabular}{|c|c|c|}
\hline Positive & & Negative impacts \\
\hline Items & Unit of analysis & Unit of analysis \\
\hline a. Additional returns & & a. Additional costs \\
\hline b. Reduced costs & & b. Reduced returns \\
\hline A. Total positive impacts & & B. Total negative impacts \\
\hline
\end{tabular}

Source: Roth et al., 2002. 
Thus, the problem confrontation score was obtained by adding weights of responses of the problems and therefore, the problem confrontation score could vary from 0-24, 0 indicating 'no problem' and 24 indicating 'highest problem'.

For making rank order, Problem Confrontation Index (PCI) was computed as used by Hossein and Miah, 2011. The PCI was computed by using the following formula:

$\mathrm{PCI}=\mathrm{P}_{\mathrm{h}} \times 3+\mathrm{P}_{\mathrm{m}} \times 2+\mathrm{P}_{1} \times 1+\mathrm{P}_{\mathrm{n}} \times 0 \ldots$

Where,

$\mathrm{P}_{\mathrm{h}}=$ Total number of farmers expressed problem as 'high';

$\mathrm{P}_{\mathrm{m}}=$ Total number of farmers expressed problem as 'medium';

$\mathrm{P}_{1}=$ Total number of farmers expressed problem as 'low'; and

$\mathrm{P}_{\mathrm{n}}=$ Total number of farmers expressed problem as 'not at all'.

Thus, PCI of any problem could range from 0 to 210,0 indicating 'no' problem confrontation and 210 indicating 'high' problem confrontation.

\section{Results and Discussion}

\subsection{Measurement of farmers' attitude towards IPM technology}

Farmers' attitude towards IPM technology was investigated in this research. The extents of opinion of the farmers against 20 statements were assessed in this regard. Attitude score for each statement was calculated by using attitude index (AI). The AI for each statement has been arranged in rank order according to their extent of opinion which appears in Table 2. Attitude Index was found to vary from 155 to 258 for all farmers.

Table 2 revealed the attitude index and ranking of the statements based on the attitude index. Farmers ranked $14^{\text {th }}$ statement positively which scored 258 in favor. Table 2 also shows that 'training is necessary to get clear knowledge about practicing IPM technology' got the $1^{\text {st }}$ rank among the statements. 'IPM is a good and effective method' got the $2^{\text {nd }}$ rank with the total AI 223. 'IPM reduces the cost of production' got the 3rd rank with the total AI 222. Most of the farmers did not agree with the statement 'IPM is a costly method' obtained $4^{\text {th }}$ rank with the total AI 221 in disfavor situation.

From the tabular representation, it was found that most of the IPM farmers had training experience, but Non-IPM farmers did not have any training experience. Majority of the farmers (including both IPM and Non- IPM farmers) had moderately favorable attitude towards IPM technology.

\subsection{Profitability analysis}

This section mainly deals with various inputs which have been used in bitter gourd production and the pricing of cost items, returns and profitability of bitter gourd that is usually produced by both IPM and Non-IPM farmers. This section also deals with partial budget analysis of using IPM technology for producing bitter gourd.

\subsubsection{Labor cost}

Labor cost is broadly classified into two categories: hired labor and family labor. Hired labor cost was calculated on the basis of wage paid to the labor. Again, family labor cost was calculated on the basis of the opportunity cost of hired labor. Family labor consists of the farmer himself, and other family members who were particularly engaged in bitter gourd production. Labor cost was measured in terms of man-day which is usually consisted of 8 (eight) hours of work by an adult male. To standardize labor hours or man-day required for different operations, all the labor units were converted into man-day equivalents (Yang, 1965). Women and children labor were converted into man-day equivalent day by presenting a ratio of 2 children $=1.5$ adult women $=1$ adult man. For avoiding complexity, average rate has been taken into account. 
Table 2. Farmers' attitude towards IPM technology (statement-wise attitude score of the farmers)

\begin{tabular}{|c|c|c|c|c|c|c|c|c|}
\hline \multirow{2}{*}{$\begin{array}{l}\text { S1. } \\
\text { No. }\end{array}$} & \multirow[b]{2}{*}{ Statements } & \multicolumn{5}{|c|}{ Extent of opinion } & \multirow[b]{2}{*}{ AI } & \multirow{2}{*}{$\begin{array}{l}\text { Rank } \\
\text { order }\end{array}$} \\
\hline & & $\begin{array}{l}\text { Strongly } \\
\text { agree }\end{array}$ & Agree & $\begin{array}{c}\text { No } \\
\text { opinion }\end{array}$ & Disagree & $\begin{array}{l}\text { Strongly } \\
\text { disagree }\end{array}$ & & \\
\hline 1 & $\begin{array}{l}\text { IPM has no harmful effect on } \\
\text { the users }\end{array}$ & 28 & 9 & 33 & 0 & 0 & 205 & 10 \\
\hline 2 & IPM is environmental friendly & 22 & 12 & 36 & 0 & 0 & 196 & 14 \\
\hline 3 & $\begin{array}{l}\text { IPM is a good and effective } \\
\text { method }\end{array}$ & 34 & 15 & 21 & 0 & 0 & 223 & 2 \\
\hline 4 & $\begin{array}{l}\text { Pests can be controlled by } \\
\text { mechanical method }\end{array}$ & 3 & 29 & 38 & 0 & 0 & 175 & 18 \\
\hline 5 & $\begin{array}{l}\text { Use of insecticides is more } \\
\text { harmful for environment than } \\
\text { better yield of vegetables }\end{array}$ & 24 & 9 & 32 & 5 & 0 & 192 & 16 \\
\hline 6 & IPM is a costly method (-) & 0 & 0 & 24 & 11 & 35 & 221 & 4 \\
\hline 7 & $\begin{array}{l}\text { Pesticide use is the only way to } \\
\text { control pests (-) }\end{array}$ & 0 & 10 & 19 & 5 & 36 & 207 & 9 \\
\hline 8 & $\begin{array}{l}\text { Better vegetable production is } \\
\text { possible by using IPM }\end{array}$ & 31 & 7 & 32 & 0 & 0 & 209 & 7 \\
\hline 9 & $\begin{array}{l}\text { Pests can be controlled by } \\
\text { cultural operation }\end{array}$ & 8 & 13 & 39 & 8 & 2 & 157 & 20 \\
\hline 10 & $\begin{array}{l}\text { Fruit fly can be controlled by } \\
\text { pheromone trap }\end{array}$ & 29 & 13 & 28 & 0 & 0 & 211 & 6 \\
\hline 11 & $\begin{array}{l}\text { IPM reduces the dependency on } \\
\text { insecticides }\end{array}$ & 31 & 12 & 27 & 0 & 0 & 214 & 5 \\
\hline 12 & $\begin{array}{l}\text { It is needed to use insecticides } \\
\text { just after pest attack (-) }\end{array}$ & 0 & 0 & 30 & 12 & 28 & 208 & 8 \\
\hline 13 & $\begin{array}{l}\text { IPM keeps the ecological } \\
\text { balance }\end{array}$ & 27 & 9 & 34 & 0 & 0 & 203 & 11 \\
\hline 14 & $\begin{array}{l}\text { Training is necessary to get } \\
\text { clear knowledge about } \\
\text { practicing IPM technology }\end{array}$ & 48 & 22 & 0 & 0 & 0 & 258 & 1 \\
\hline 15 & IPM is a complex method (-) & 0 & 9 & 26 & 8 & 27 & 193 & 15 \\
\hline 16 & $\begin{array}{l}\text { IPM does not prevent the side } \\
\text { effects of insecticides (-) }\end{array}$ & 0 & 0 & 38 & 20 & 12 & 184 & 17 \\
\hline 17 & $\begin{array}{l}\text { Pests can be controlled by } \\
\text { biological control }\end{array}$ & 10 & 14 & 42 & 4 & 0 & 170 & 19 \\
\hline 18 & $\begin{array}{l}\text { IPM reduces the cost of } \\
\text { production }\end{array}$ & 35 & 12 & 23 & 0 & 0 & 222 & 2 \\
\hline 19 & $\begin{array}{l}\text { Use of IPM practices increase } \\
\text { vegetable quality }\end{array}$ & 29 & 4 & 37 & 0 & 0 & 202 & 12 \\
\hline 20 & $\begin{array}{l}\text { IPM does not prevent the } \\
\text { indiscriminate use of pesticides } \\
(-)\end{array}$ & 0 & 2 & 33 & 8 & 27 & 200 & 13 \\
\hline
\end{tabular}


Thus, the average calculated wage rate was Tk 300 per man-day depending on the season and availability of day labor in the study areas. Cost of labor was estimated at Tk 103360, 97450 and 96515 for marginal, small and medium farmers, respectively for IPM farmers (Table 3), whereas it was estimated to be Tk 117985, 113348 and 109223 for marginal, small and medium farmers, respectively in case of Non-IPM framers (Table 3). Considering all farmers, total labor cost was Tk 98580 and Tk 114349 for IPM and Non-IPM farmers respectively. In fact Non-IPM farmers used more labor for fertilizers, insecticides, etc. application (Table 3), which was also statistically significant.

\subsubsection{Cost of power tiller}

The use of power tiller was mainly for cultivating the land and preparing for production of bitter gourd. In the study areas, farmers used power tiller on the basis of rent. Data in Table 3 show that per hectare cost of power tiller for marginal, small and medium farmers were $\mathrm{Tk}$ 5687, 5806 and 5485, respectively in case of IPM farmers. In case of Non-IPM farmers, per hectare cost of power tiller for marginal, small and medium farmers were Tk 5731, 5746 and 5711, respectively. The result of t-test (56.49) also revealed that Non-IPM farmers significantly spent more for land preparation.

\subsubsection{Cost of seed/seedling}

In the study areas, farmers used purchased seeds for producing bitter gourd. The average cost of seedlings per hectare for marginal, small and medium IPM farmers were Tk 14402, 14629 and 14569, respectively (Table 3 ). In case Non-IPM farmers, the average cost per hectare for marginal, small and medium farmers were Tk 17194, 17269 and 17561, respectively. It is evident that, on an average Non-IPM farmers used more number of seedlings compared to their IPM counterpart that also significantly ahead.

\subsubsection{Cost of organic fertilizer}

In the study areas cost of organic fertilizer were calculated at the prevailing market prices. Per hectare total organic fertilizer cost for marginal, small and medium farmers were Tk 12027, 11421 and 10994, respectively in case of IPM farmers where as in case of Non-IPM farmers it were Tk 8125, 8546 and 7674 respectively (Table 3 ). The average result of t-value revealed that IPM farmers used more organic fertilizer as they know that using organic fertilizer is good for both vegetables and soil as well compared to Non-IPM farmers.

\subsubsection{Cost of inorganic fertilizer}

Almost all the farmers used more or less chemical fertilizer. Urea, Triple Super Phosphate (TSP), Muriate of Potash (MoP) and Gypsum were the most commonly used fertilizer for bitter gourd production. In case of IPM farmers, per hectare inorganic fertilizer costs were Tk 33270 , 30929 and 29230 for marginal, small and medium farmers, respectively (Table 3 ). In case of Non-IPM farmers, per hectare inorganic fertilizer were Tk 64664, 63138 and 59209 for marginal, small and medium farmers, respectively (Table 3). Considering the average value of inorganic fertilizer for t-test in this regards, the result of t-value (7.89) indicated that Non-IPM farmers spent more for inorganic fertilizer.

\subsubsection{Cost of pheromone trap}

Only IPM farmers used pheromone trap to keep their bitter gourd free from insect attack. Per hectare cost of pheromone trap for marginal, small and medium farmers were Tk 4510, 4670 and 4501, respectively (Table 3). Instead of using pheromone trap Non-IPM farmers used more insecticides than IPM farmers which cost 7 times more than pheromone cost. As such the Non-IPM farmers incurred much higher cost in producing bitter gourd. 
Table 3. Cost and return of bitter gourd production for IPM and Non-IPM farmers in the study areas (Tk/ha)

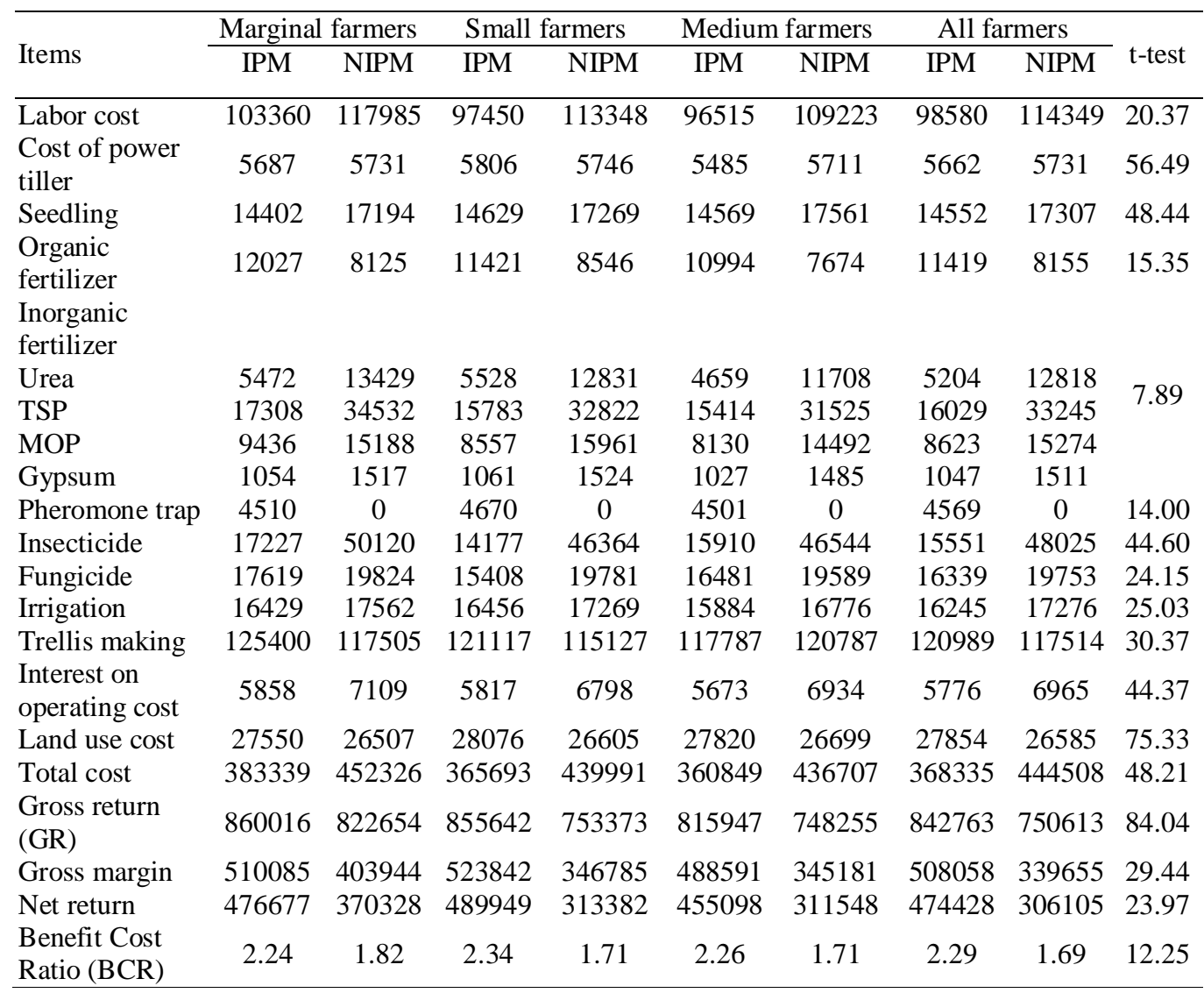

Source: Field survey, 2015

\subsubsection{Cost of insecticide}

In the study areas both IPM and Non-IPM farmers used insecticides. Per hectare cost of insecticides were Tk 17227, 14177 and 15910 for marginal, small and medium farmers, respectively in case of IPM farmers while it were Tk 50120, 46364 and 46544, respectively for Non-IPM farmers (Table 3). Non-IPM farmers didn't follow any recommended dose. In the study area most of the farmers think that the more they use pesticides the more will be the production. All though the IPM farmers know that excessive use of pesticide may damage the crop quality but they also used pesticides as their own wish but significantly less than the NonIPM farmers.

\subsubsection{Cost of fungicide}

Data in Table 3 reveal that per hectare fungicides cost were significant as Tk 17619, 15408 and 16481 for marginal, small and medium IPM farmers, respectively while it were Tk 19824, 19781 and 19589, respectively for Non-IPM farmers (Table 3). 


\subsubsection{Irrigation cost}

It is evident in Table 3 that costs incurred for irrigation were Tk 16429, 16456 and 15884 for marginal, small and medium IPM farmers, respectively. In case of Non-IPM farmers cost incurred for irrigation were Tk 17562, 17269 and 16776 for marginal, small and medium farmers, respectively. However considering all farmers, costs incurred for irrigation were Tk 16245 and Tk 17276 for IPM and Non-IPM farmers, respectively. The result of t-test (25.03) indicated that there was a significant difference of irrigation cost between IPM and Non-IPM farmers for bitter gourd production.

\subsubsection{Cost of trellis making}

In case of IPM farmers per hectare cost of trellis making were significant but negative for marginal, small and medium farmers, estimated to be Tk 125400, 121117 and 117787 , respectively while it were Tk 117505, 115127 and 120787, respectively for Non-IPM farmers (Table 3).

\subsubsection{Interest on operating cost}

From the Table 3 it was found that per hectare interest on operating cost significantly estimated at Tk 5858, 5817 and 5673 for marginal, small and medium IPM farmers, respectively. However, the corresponding costs were Tk 7109, 6798 and 6934, respectively for Non-IPM farmers.

\subsubsection{Land use cost}

Land use cost was calculated by using per hectare lease value of land which affected bitter gourd production in the study areas. This lease value varies from one place to another which depends on its location, soil fertility, topography of the soil, distance from the sources of water, etc. Table 3 shows that the estimated land use costs of marginal, small and medium farmers were $\mathrm{Tk} 27550,28076$ and 27820 for IPM farmers, respectively while it were Tk 26507, 26605 and 26699, respectively for Non-IPM farmers. The result of t-value (75.33) also significantly impact on bitter gourd production for IPM farmers.

\subsubsection{Total cost}

Total cost was calculated by adding up all the costs of inputs and other pertinent factors which significantly impact on bitter gourd production. Total costs incurred for producing bitter gourd were Tk 383339, 365693 and 360849 for marginal, small and medium IPM farmers, respectively (Table 3 ). On the other hand, NonIPM farmers incurred Tk 452326, 439991 and 439991 for marginal, small and medium farmers, respectively (Table 3 ). The average per hectare total cost was Tk 368335 and Tk 444508 for IPM and Non-IPM farmers, respectively in the study areas.

\subsubsection{Gross Return (GR)}

The average per hectare gross return were $\mathrm{Tk}$ 860016,855642 and 815947 for marginal, small and medium IPM farmers, respectively while it were Tk 822654, 753373 and 748255, respectively for Non-IPM farmers (Table 3). Considering all farmers per hectare gross return was Tk 842763 and Tk 750613 for IPM and Non-IPM farmers, respectively in the study areas (Table 3). The result of t-value (84.04) revealed that IPM farmers were benefitted for bitter gourd production compared to Non-IPM farmers.

\subsubsection{Gross Margin (GM)}

In the study area gross margin of marginal, small and medium farmers were estimated to be Tk 510085,523842 and 488591 in case of IPM farmers while it were $\mathrm{Tk} 403944,346785$ and 345181 for Non-IPM farmers (Table 3). On an average per hector gross margin of IPM farmers (Tk 508058) was higher than per hector gross margin of Non-IPM farmers (Tk 339655). It was also significant for IPM farmers.

\subsubsection{Net Return (NR)}

Per hectare net returns were estimated at $\mathrm{Tk}$ 476677, 489949 and 455098 for marginal, small and medium farmers in case of IPM farmers, respectively (Table 3 ). On the other hand, for Non-IPM farmers per hectare net return were Tk 370328, 313382 and 311548 for marginal, small and medium farmers, respectively (Table 3 ). The average per hectare net return was Tk 474428 
and Tk 306105 for IPM and Non-IPM farmers, respectively (Table 3 ).

\subsubsection{Benefit Cost Ratio (BCR)}

Data in Table 3 reveal that in case of IPM farmers the overall BCR (undiscounted) of marginal, small and medium farmers were 2.24, 2.34 and 2.26 indicating that bitter gourd production is highly profitable but it was statistically insignificant for IPM farmers. On the other hand, BCR were 1.82, 1.71 and 1.71 for marginal, small and medium farmers in case of Non-IPM farmers which also indicate that bitter gourd production is profitable (Table 3). Irrespective of all farms in the study area, cultivation of bitter gourd was profitable since BCR were 2.29 and 1.69 for IPM and Non-IPM farmers, respectively (Table 3). Islam et al. (2013) conducted a study on economic impact of IPM technology on bitter gourd production. In that study the cultivation of bitter gourd was also profitable since undiscounted BCR were 2.08 and 1.79 for IPM and Non-IPM farmers respectively. It is evident that, in the study area bitter gourd production is highly profitable under IPM farmers than the Non-IPM farmers.

\subsection{Partial budget analysis}

Table 4 indicates that per hectare additional return of using IPM technology was Tk 92150 for bitter gourd production. This is due to increased quantity of bitter gourd output. The operating costs that can be reduced if farmers use IPM technology is: cost of hired labor, seed or seedlings cost, cost of fertilizer, insecticides and fungicides estimated to be Tk 10127, 2755, 31945 , 32474 and 3414, respectively and per hectare total costs reduced by using IPM technology was Tk 80715 for bitter gourd production (Table 4). The added expenses that IPM farmers had to incur by using IPM technology are the cost of organic fertilizer, pheromone trap cost and cost of trellis making estimated at Tk 3264, 4569 and 3475, respectively (Table 4). Data also show that per hectare total additional cost of using IPM technology was Tk 11308 for bitter gourd production. Table 4 shows that per hectare net benefit was positive and estimated at Tk 161557 for bitter gourd production. It is evident from the partial budget analysis that use of IPM technology is profitable. So, farmers should use IPM technology for producing bitter gourd.

Table 4. Partial budget analysis of using IPM technology versus Non-IPM (Conventional method) for producing bitter gourd

\begin{tabular}{|c|c|c|c|}
\hline \multicolumn{2}{|c|}{ Positive impacts } & \multicolumn{2}{|c|}{ Negative impacts } \\
\hline Items & (Tk/ha) & Items & (Tk/ha) \\
\hline & & a. Additional costs & \\
\hline a. Additional return & 92150 & Organic fertilizer & 3264 \\
\hline & & Pheromone trap & 4569 \\
\hline & & Trellis making & 3475 \\
\hline & & Total additional costs & 11308 \\
\hline b. Reduced costs & & & \\
\hline Hired labor & 10127 & b. Reduced return & 0 \\
\hline Seedling & 2755 & & \\
\hline Inorganic fertilizer & 31945 & & \\
\hline Insecticide & 32474 & & \\
\hline Fungicide & 3414 & & \\
\hline Total reduced costs & 80715 & & \\
\hline A. Total positive impacts & 172865 & B. Total negative impacts & 11308 \\
\hline
\end{tabular}

Source: Field survey, 2015. 


\subsection{Problem confrontation index (PCI)}

Various problems were faced by the farmers in adopting and practicing IPM technology in the study areas. The computed PCI of the 8 problems ranged from 42 to 184 (against a possible range from 0 to 210) and have been arranged in rank order according to their problem indices which appears in Table 5.

Majority of the farmers point out that lack of proper training facilities was the main problem in the study areas in practicing and adopting IPM technology. It was also a major problem faced by the Non-IPM farmers in case of adopting IPM technology because they did not get any training on practicing IPM technology and detailed information about this technology. Out of 70 farmers, 51 farmers confronted this problem at high extent, 15 farmers confronted at medium extent, 1 farmer confronted at low extent and about only 3 farmers did not confronted this problem. In this case, the computed value of PCI was $184[(51 \times 3)+(15 \times 2)+(1 \times 1)]$ against a possible range from 0 to 210 and hence was considered as the $1^{\text {st }}$ ranked problem.

A good number of farmers point out that, lack of technological knowledge in using IPM technology was an important problem in the study areas. Basically, the reason behind this was the lack of training facilities in the study areas. Most of the farmers did not have clear ideas about IPM technology. In this case, the calculated value of PCI was $160[(36 \times 3)+$ $(18 \times 2)+(16 \times 1)$ ] against a possible range from 0 to 210 and was considered as the $2^{\text {nd }}$ ranked problem.

In this way, comparatively fewer problem confronted by the farmers was unavailability of pheromone trap, that means it was not a serious problem by the farmers. This is due to because, it was available in the local market, was not costly and farmers might easily get it if they wish to use it in the farming system.

During interview with the farmers, they were asked to indicate probable suggestions to overcome the problems in practicing and adopting IPM technology. Majority of the farmers suggested that training facilities should be improved. The rate of adoption of IPM technology is still slow, which is mainly due to the ignorance of the growers about IPM. Therefore, adequate training should be provided to the vegetable growers on different aspects of IPM technology so that the rate of adoption could be gradually increased. Farmers awareness and motivation could be increased through training, setting demonstration plot, group meeting of farmers, field day etc.

Table 5. Summary of farmers' problem confrontation along with rank order

\begin{tabular}{|c|c|c|c|c|c|c|c|}
\hline \multirow[t]{2}{*}{$\begin{array}{l}\text { SL } \\
\text { No. }\end{array}$} & \multirow[t]{2}{*}{ Problems } & \multicolumn{4}{|c|}{$\begin{array}{l}\text { Extent of problem confrontation } \\
\qquad(\mathrm{N}=70)\end{array}$} & \multirow[t]{2}{*}{ PCI } & \multirow{2}{*}{$\begin{array}{l}\text { Rank } \\
\text { order }\end{array}$} \\
\hline & & $\begin{array}{l}\text { High } \\
\text { (3) }\end{array}$ & $\begin{array}{l}\text { Medium } \\
\text { (2) }\end{array}$ & $\begin{array}{c}\text { Low } \\
(1)\end{array}$ & $\begin{array}{l}\text { Not at all } \\
(0)\end{array}$ & & \\
\hline 1 & Lack of proper training facilities & 51 & 15 & 1 & 3 & 184 & 1 \\
\hline 2 & $\begin{array}{l}\text { Lack of technological knowledge in using } \\
\text { IPM technology }\end{array}$ & 36 & 18 & 16 & 0 & 160 & 2 \\
\hline 3 & Weak extension services & 38 & 15 & 14 & 3 & 158 & 3 \\
\hline 4 & Unavailability of pheromone trap & 0 & 12 & 18 & 40 & 42 & 8 \\
\hline 5 & Labor scarcity & 11 & 17 & 6 & 36 & 73 & 5 \\
\hline 6 & $\begin{array}{l}\text { Lack of knowledge on the harmful effect } \\
\text { of insecticides }\end{array}$ & 2 & 16 & 13 & 39 & 51 & 6 \\
\hline 7 & Unavailability of skilled labor & 17 & 11 & 5 & 37 & 78 & 4 \\
\hline 8 & Lack of awareness & 3 & 9 & 23 & 35 & 50 & 7 \\
\hline
\end{tabular}

Source: Field survey, 2015.Note: PCI = Problem confrontation index (Possible score range 0 to 210). 
Knowledge of the input retailers and Sub Assistant Agricultural Officers (SAAOs) on IPM should be increased through training exposure; visit etc. in order to provide appropriate service to the farmers. Extension services should be improved because the present study observed lack of coordination between farmers and extension workers in the study areas. There should be an opportunity to get services by the extension workers in time of necessity. DAE should take initiative to increase IPM technology adoption and proper practices of this technology for more profitable vegetable as well as crop production without harming the environment. Community approach should be done to popularize IPM method. Educated, commercially oriented and lead farmers should be involved to introduce IPM technology at farmers' level for vegetable and crop production to increase farm income. More IPM clubs should be involved to introduce IPM technology at farmers' level.

The reasonable price of the IPM-applied vegetables should be ensured through cooperative markets or growers' market so that the growers are motivated to use IPM and grow vegetables and other crops that are safe and of superb quality.

\section{Conclusions and Recommendation}

Findings of the study and the logical interpretation of their meanings in the light of other relevant facts enabled the researcher to draw the following conclusions:

It can be concluded that bitter gourd production was profitable in the study areas under both IPM and Non-IPM farmers. The average net return of per hectare were estimated at Tk 474428 and Tk 306105 for IPM and Non-IPM farmers, respectively which indicated that bitter gourd production under IPM farmers was more profitable than the Non-IPM farmers. BCR was also higher for IPM farmers than Non-IPM farmers. It was evident from the partial budget analysis that use of IPM technology was highly profitable and net benefit was Tk 161557. Thus, if farmers produce more bitter gourd in the same land by using IPM technology, it might be an ample scope to increase the economic benefits in the study areas. Due to various problems in practicing and adopting IPM technology framers were not received the benefit of using IPM technology. Based on economic benefits of IPM technology, farmers suggested the probable solutions to get rid of those problems.

On the basis of findings and conclusions of the study the following recommendations are made:

i. The training facilities should be increased. For the better adoption and practices of this technology farmers need better skills and knowledge.

ii. The extension services need to be strengthened to increase coordination between farmers and extension workers.

iii. IPM related publicity should be promoted through the mass media and awareness on dangers of pesticides, pesticide residues in food, health and environmental hazards of pesticides need to be created.

iv. GoB should make an annual budget allocation for IPM activities and place the fund with the National IPM Program. As a result more farmers could be interested on adopting IPM practices in future.

\section{References}

Ahmed, J. 2010. Attitude of Farmers towards the Effect of Pond Ownership of Fish Cultivation. MS Thesis, Department of Agricultural Extension Education, Bangladesh Agricultural University, Mymensingh, Bangladesh.

Anonymous, 2015. Vegetables Farming Using Eco-Friendly Pheromone Trap Gains Popularity in Rangpur. Published in The New Nation, September 7, 2015.

Barnard, C. S. and J. S. Nix 1999. Farm Planning and Control, Cambridge University Press.

BBS 2013. Yearbook of Agricultural Statistics of Bangladesh, Ministry of Planning, Government of the People's Republic of Bangladesh, Dhaka. 
Chowdhuri, M. 2011. A Comparative Economic Analysis of Small Scale and Commercial Vegetables Production in Selected Areas of Gazipur District. MS Thesis, Department of Agricultural Economics, Bangladesh Agricultural University, Mymensingh, Bangladesh.

Dillon, J. L. and J. B. Hardaker 1993. Farm Management Research for Small Farmers' Development. Food and Agriculture Organisation of the United Nations, Rome, Italy.

FAO 2001. Integrated Pest Management (IPM). Report of the Evaluation Mission of IPM Projects in Bangladesh. Food and Agriculture Organisation of the United Nations. Rome, Italy.

Hoque, M. K. 2001. Environmental Awareness and Problem Confrontation of the FFS Farmers in Practicing IPM. MS Thesis, Department of Agricultural Extension Education, Bangladesh Agricultural University, Mymensingh, Bangladesh.

Hossain, M. S. and M. A. M. Miah 2011. Poor Farmers' Problem Confrontation in Using Manure towards Integrated Plant Nutrition System. Bangladesh Journal of Extension Education, 23 (1\&2), 139-147.

Islam, M. N. 2014. Impact of IPM Technology on Productivity and Technical Efficiency of Selected Crops in Bangladesh. PhD Thesis, Department of Agricultural Economics, Bangabandhu Sheikh Mujibur Rahman Agricultural University, Gazipur, Bangladesh.

Islam, Q. M. S., M. Mohiuddin, M. G. Rabbaniand A. F. Mollah 2013. Economic Impact of IPM Technology on Bitter Gourd Production in Selected Areas of
Bangladesh. International Journal of Applied Research in Business Administration \& Economics, 2 (6), 2-8.

Nasiruddin, M., S. N. Alam, , M. Khorsheduzzaman, , H. S. Jasmine, A. N. M. R. Karim and E. Rajotte. 2015. Article on Management of Cucurbit Fruit Fly, Bactrocera Cucurbitae, in Bitter Gourd by Using Pheromone and Indigenous Bait Traps and Its Effect on Year-Round Incidence of Fruit Fly. BARI, Joydebpur, Gazipur, Bangladesh.

Rashid, B. 2001. Farmers' Attitude towards Integrated Pest Management in Phulpur Upazila under Mymensingh District. $M S$ Thesis, Department of Agricultural Extension Education, Bangladesh Agricultural University, Mymensingh, Bangladesh.

Roth, S., D. Allience, and J. Hyde 2002. Partial Budgeting for Agricultural Business. College of Agricultural Sciences, Pennsylvania State University, University Park, PA, United States.

Stern, V. M., R. F. Smith, R. V. Bosch and K. S. Hagen 1959. The Integrated Control Concept. Hilgardia, 29, 81-110.

Suraiya, Z. 2008. An Economic Analysis of Some Selected Summer Vegetables Production in Purbadhala Upazila of Netrokona District. MS Thesis, Department of Agricultural Economics, Bangladesh Agricultural University, Mymensingh, Bangladesh.

Yang, W. Y. 1965. Methods of Farm Management Investigation for Improving Farm Productivity, Food and Agriculture Organization of the United Nations, Rome, Italy. 